\title{
Whole-plant carbon relations and root respiration associated with root tolerance to high soil temperature for Agrostis grasses
}

Eric M. Lyons, John Pote, Michelle DaCosta, and Bingru Huang

This is the peer reviewed version of the article, which has been published in final form at https://doi.org/10.1016/j.envexpbot.2006.04.002 @ 2007. This manuscript version is made available under the CC-BY-NC-ND 4.0 license http://creativecommons.org/licenses/by-nc-nd/4.0/.

Suggested Citation: Lyons, Eric M., Pote, John, DaCosta, Michelle, and Huang, Bingru (2007), Whole-plant carbon relations and root respiration associated with root tolerance to high soil temperature for Agrostis grasses, Environmental and Experimental Botany, 59(3): 307-313. https://doi.org/10.1016/j.envexpbot.2006.04.002 


\title{
Whole-plant carbon relations and root respiration associated with root tolerance to high soil temperature for Agrostis
}

\section{grasses}

\author{
Eric M. Lyons, John Pote, Michelle DaCosta, and Bingru Huang
}

Affiliation: Department of Plant Biology and Pathology, Rutgers University, 59 Dudley Road, New Brunswick, NJ 08901, United States

Abstract: Plant tolerance to high soil temperature may be related to the adjustment in carbon production and utilization. The objective of this study was to determine changes in whole-plant carbon balance and root respiration rate in relation to root tolerance to high soil temperature for two Agrostis grass species varying in heat tolerance. Plant tolerance to high soil temperature was compared between Agrostis scabra, a thermal grass species adapted to chronic high-temperature soils in the geothermal areas in Yellowstone National Park, and creeping bentgrass (Agrostis stolonifera), a cultivated grass species adapted to cool climatic regions. Plant roots were exposed to low soil temperature $\left(20^{\circ} \mathrm{C}\right)$ or high soil temperature $\left(37^{\circ} \mathrm{C}\right)$ for 17 days in water baths placed in a controlled-environment growth chamber. Root biomass and cell membrane stability were determined to evaluate root thermotolerance of both species. Canopy photosynthetic rate $(\mathrm{Pn})$, whole-plant respiration rate, root respiration rate, and total non-structural carbohydrate (TNC) content were measured to assess changes in carbon production and utilization in response to high soil temperature. Root biomass and cell membrane stability declined with increasing soil temperature, but the decline was much less for $A$. scabra than $A$. stolonifera, suggesting that roots of $A$. scabra were more tolerant to heat stress. Canopy $\mathrm{Pn}$ decreased and whole-plant respiration rate increased for $\mathrm{A}$. stolonifera, but canopy $\mathrm{Pn}$ and respiration rate were unchanged for $A$. scabra in response to increasing soil temperature. After 17 days of high soil temperature treatment, A. stolonifera exhibited carbon deficit at the whole-plant level, whereas $A$. scabra maintained positive carbon gain. Root respiration of plants previously grown at $20^{\circ} \mathrm{C}$ increased after a short-term treatment $(24 \mathrm{~h})$ at $37^{\circ} \mathrm{C}$, but the increase was 
significantly lower for $A$. scabra than for $A$. stolonifera. TNC content in roots did not show response to short-term ( $24 \mathrm{~h}$ ) changes in temperature and did not exhibit species variations. Leaves of $A$. scabra, however, maintained TNC content under both low and high temperature regimes. Our results suggest that root thermotolerance of cool-season grasses could be related to the maintenance of positive whole-plant carbon balance, and down-regulation of whole-plant and root respiration rates in response to increasing soil temperature.

Keywords: Agrostis scabra; Agrostis stolonifera; Carbon; Heat stress; High soil temperature

\section{Introduction}

High soil temperature is a major environmental factor limiting growth and productivity for cool-season plants (Kuroyanagi and Paulsen, 1988; Ruter and Ingram, 1990, 1992; Udomprasert et al., 1995; Xu and Huang, 2000a,b, 2001). Roots may play critical roles in plant survival in environments with high soil temperature, because of their low optimum temperature range for growth (Nielsen, 1974) and many root functions are sensitive to heat stress (McMichael and Burke, 1999). Shoot responses to high temperature stress have been studied extensively. However, roots have been investigated much less than above-ground parts because soil limits their accessibility, in spite of their importance to whole plant responses to environmental stresses (McMichael and Taylor, 1987). The mechanisms associated with root tolerance to high soil temperature are not well understood.

Among the physiological factors that influence root growth and functions, carbohydrate metabolism of roots, including utilization, is fundamentally important, because roots are completely dependent on carbon assimilates supplied by leaves (Lambers et al., 1999). The disturbance of carbohydrate metabolism in roots has been suggested as a primary factor responsible for growth inhibition and dysfunctions of roots grown at high soil temperature (Du and Tachibana, 1994). In order to survive prolonged high soil temperature, roots must maintain carbon supply from shoots and/or must be efficient in carbon utilization when carbon availability is limited. Studies on creeping bentgrass 
(Agrostis stolonifera) found that removal of photosynthesizing leaves by mowing grass to a low canopy height $(3 \mathrm{~mm}$ ) reduced root life span, especially during times of high soil temperature (Liu and Huang, 2002), which could be attributable to the reduced carbohydrate availability in roots and carbon supply from shoots (Xu and Huang, 2003). A tissue may die if its maintenance requirements are not met or if respiration is so high that sugar reserves are depleted. Elevated root respiration has been observed at high soil temperature, possibly resulting in carbohydrate depletion and root senescence (Klock et al., 1997; Xu and Huang, 2000b).

The optimum soil temperature for root growth of most C3, cool-season grasses range from 10 to $18^{\circ} \mathrm{C}$ (Fry and Huang, 2004) and root death was observed when soil temperature reached $23^{\circ} \mathrm{C}$ in cool-season creeping bentgrass ( $A$. stolonifera var. pulastris) (Pote et al., in press). However, some C3 grass species are able to survive chronically high soil temperature in geothermally-heated areas of Yellowstone National Park (YNP) (Stout and Al-Niemi, 2002). Agrostis scabra ("thermal" rough bentgrass) is one of the predominant grass species in the thermal areas (Tercek et al., 2003). Plants in geothermal areas in YNP are commonly exposed to chronic soil temperatures of up to $50^{\circ} \mathrm{C}$, even though air temperature is typically below $25^{\circ} \mathrm{C}$ (Stout and Al-Niemi, 2002). It is unclear how roots of these thermal grasses can survive or even grow at such high soil temperature, while other cool-season grasses cannot survive at these temperature levels. Specifically, whether changes in whole-plant carbon balance and carbon utilization in roots are associated with heat tolerance of cool-season grass species is not well documented. Therefore, the objective of this study was to examine changes in whole-plant carbon balance and root respiration rate in relation to root tolerance to high soil temperature for two Agrostis grass species varying in heat tolerance. We hypothesized that thermal $A$. scabra was better able to adjust whole-plant carbon balance and root carbon utilization through respiration in response to increasing soil temperature, in comparison to a heat-sensitive cool-season turfgrass species, $A$. stolonifera. 


\section{Materials and methods}

\subsection{Plant material and growth conditions}

Tillers from A. stolonifera (cv. L-93) plants and a thermal A. scabra ecotype ('FTAS') collected in Yellowstone National Park, Wyoming were transplanted into clear polyethylene bags ( $5 \mathrm{~cm}$ in diameter and $40 \mathrm{~cm}$ in length) filled with sand $(0.2-0.5 \mathrm{~mm}$ particle size). The plants were first maintained in the greenhouse for approximately 60 days for leaf canopy and root establishment, and then transferred into water baths, which were maintained in a controlled-environment growth chamber. The polyethylene bags (with drainage holes at the bottom) were placed in polyvinylchloride (PVC) tubes with same diameter and length, and then installed inside a water bath (see detailed description below). The growth chamber was set at $20 / 16^{\circ} \mathrm{C}$ (day/night), photosynthetic photon flux density of $400 \mu \mathrm{mol} \mathrm{m} \mathrm{m}^{-2} \mathrm{~s}^{-1}$, and photoperiod of $12 \mathrm{~h}$. Grass canopy was maintained at a $2 \mathrm{~cm}$ height by cutting weekly and fertilized weekly with $50 \mathrm{~mL}$ fullstrength Hoagland's nutrient solution (Hoagland and Arnon, 1950). Plants were irrigated daily before imposing high soil temperature and twice daily during the high temperature treatment to maintain soil moisture at field capacity.

\subsection{Treatments}

Roots of plants were exposed to $20^{\circ} \mathrm{C}$ (low temperature control) or $37^{\circ} \mathrm{C}$ (high soil temperature) in water baths for 17 days, while shoots were exposed to an ambient temperature of $20^{\circ} \mathrm{C}$. The high temperature treatment was repeated in four water baths. The design of the soil-temperature controlled water bath was previously described by Xu and Huang (2001). Briefly, the bath was made from PVC sheets and had dimensions of $75 \mathrm{~cm}$ (length) $\times 72 \mathrm{~cm}$ (width) $\times 40 \mathrm{~cm}$ (height). Inside the box, PVC tubes $(5 \mathrm{~cm}$ in diameter, $43 \mathrm{~cm}$ in length) were installed through holes cut from the bottom PVC sheet to allow for drainage. The box was filled with water and water temperature was regulated by an immersion circulating heater (MR 25-1-X, Process Technology, Mentor, $\mathrm{OH}$ ) and an aquarium pump for water circulation to maintain uniform temperature of the water bath. Sand-filled polyethylene bags containing plants were then placed inside the PVC tubes installed in the water bath. The design allowed for the water bath to maintain constant, predetermined root temperature, while maintaining canopy temperature close 
to the ambient level in the growth chamber. The actual canopy temperature averaged $23^{\circ} \mathrm{C}$ during the treatment period.

For the determination of root respiration and carbohydrate status in response to shortterm changes in root temperature, roots that were previously grown at 20 or $37^{\circ} \mathrm{C}$ in the water bath were then transferred into nutrient solution for $24 \mathrm{~h}$ at 20 or $37^{\circ} \mathrm{C}$. The shortterm temperature treatments were composed of (1) growth temperature at $20^{\circ} \mathrm{C}$ and measurement temperature at $20^{\circ} \mathrm{C}(\mathrm{LL}) ;(2)$ growth temperature at $20^{\circ} \mathrm{C}$ and measurement temperature at $37^{\circ} \mathrm{C}(\mathrm{LH}) ;(3)$ growth temperature at $37^{\circ} \mathrm{C}$ and measurement temperature at $37^{\circ} \mathrm{C}(\mathrm{HH})$; and (4) growth temperature at $37^{\circ} \mathrm{C}$ and measurement temperature at $20^{\circ} \mathrm{C}(\mathrm{HL})$.

\subsection{Measurements}

Canopy net photosynthetic rate $(\mathrm{Pn})$ and whole-plant respiration rate were measured using an infrared gas-exchange analyzer (LiCor 6400, LiCor Inc., Lincoln, NE) with a custom-designed leaf canopy chamber at 17 days of treatment prior to destructive sampling for other analysis. The leaf canopy chamber was constructed of a clear acrylic tube ( $8 \mathrm{~cm}$ diameter, $10 \mathrm{~cm}$ in height) and a PVC joining-collar that fit tightly over the PVC tubes containing plants in the water bath. The top of the canopy chamber was covered with transparent propa-film (Licor Inc., Lincoln, NE) for light penetration during photosynthesis measurement. Canopy $\mathrm{Pn}$ was measured at approximately $5 \mathrm{~h}$ into the $12 \mathrm{~h}$ photo period and whole-plant dark respiration rate was measured at approximately $3 \mathrm{~h}$ into the dark period. Canopy $\mathrm{Pn}$, whole-plant respiration rate, and all following measurements were performed on four replicates per treatment for each plant species.

Following the gas exchange measurements, plants were removed from the water bath and roots were washed free of sand for measurement of root respiration. The whole plant was then transferred into $250 \mathrm{~mL}$ Erlenmyer flasks, where the root system was submerged in 1/4-strength Hoagland's solution while shoots were exposed to the ambient temperature. The hydroponic solution in each flask was aerated via a circulating pump (Apollo Enterprises Inc., Oxnard, CA, USA) maintaining an open-flow system. Flasks were submerged in a water bath to maintain root temperature at either 20 or $37^{\circ} \mathrm{C}$, while shoots were exposed to the ambient air temperature $\left(20^{\circ} \mathrm{C}\right)$ of the 
growth chamber. After a $24 \mathrm{~h}$ period, a closed-flow system was created by connecting the exit air from the Erlenmyer to a circulating pump. Roots were sealed airtight inside the flask using a rubber stopper around the shoot base and vacuum grease in order to measure $\mathrm{O}_{2}$ depletion rate due to root consumption. A $5 \mathrm{~mL}$ aliquot of incubation solution was removed from the flask every $10 \mathrm{~min}$ for $60 \mathrm{~min}$ and injected into a temperature-controlled oxygen electrode (Kansatech, PPI Systems, Burlington, MA) to determine $\mathrm{O}_{2}$ consumption rate or root respiration rate. Root respiration rates were calculated from the linear portion of the $\mathrm{O}_{2}$ depletion graph for each sample.

Cell membrane stability was determined by measuring amino acid leakage from root cells. Fresh root samples weighing $0.1 \mathrm{~g}$ were immersed in $10 \mathrm{~mL}$ of deionized water and placed in a vacuum at $48 \mathrm{kPa}$ for $1 \mathrm{~h}$. The samples were shaken for $24 \mathrm{~h}$, and a 2 $\mathrm{mL}$ sample was then taken from the incubation solution to measure amino acid levels. Following reaction with ninhydrin (Rosen, 1957), the absorbance was read at 570 and $440 \mathrm{~nm}$ using a spectrophotometer (Spectronic Genesys Series, Spectronic Instruments Inc., Rochester, NY) to determine the amount of amino acids in the incubation solution leaked from the roots (Larkindale and Huang, 2004). Amino acid leakage is expressed as a percent of the total amino acids in the incubation solution before and after temperature treatments.

Root biomass was determined after roots were dried in an oven at $80^{\circ} \mathrm{C}$ for $72 \mathrm{~h}$. Dried roots and shoots were ground into fine powder for the analysis of total non-structural carbohydrates (TNC). TNC content was measured for two sub-samples per replication using the method described by Ting (1959) with modifications. Briefly, $40 \mathrm{mg}$ of ground tissues were transferred to glass tubes containing $2.5 \mathrm{~mL}$ of $5.0 \%$ amylase and incubated at $37^{\circ} \mathrm{C}$ for $24 \mathrm{~h}$. After $24 \mathrm{~h}$ incubation period, $0.5 \mathrm{~mL}$ of $0.6 \mathrm{~N} \mathrm{HCl}$ was added to the solution for an additional $18 \mathrm{~h}$. The solution was then neutralized with $10 \mathrm{~N} \mathrm{NaOH}$ and diluted to $50 \mathrm{~mL}$ with distilled water and filtered. Reducing sugars were measured by taking $1.0 \mathrm{~mL}$ of the solution and adding $1.5 \mathrm{~mL}$ of alkaline ferricyanide solution. The mixture was heated for $10 \mathrm{~min}$ in a $100^{\circ} \mathrm{C}$ water bath and quickly cooled under running water. The $\mathrm{pH}$ of the solution was partially neutralized with $3.0 \mathrm{~mL}$ of $2 \mathrm{~N} \mathrm{H}_{2} \mathrm{SO}_{4}$. Finally, $1.2 \mathrm{~mL}$ of arsenomollybdate solution was added and the total volume was adjusted to 
$25 \mathrm{~mL}$ with distilled water. Absorbance of the solution was measured at $515 \mathrm{~nm}$ using a spectrophotometer (Spectronic Genesys Series, Spectronic Instruments Inc., Rochester, NY) and compared to a standard curve to determine TNC content.

\subsection{Statistical analysis}

The experiment was a completely randomized block design with four replicates. Analysis of variance was conducted (PROC MIXED SAS 8.02, SAS Institute, Cary, NC, USA) to determine the effects of root temperature on root biomass, cell membrane stability, root respiration rate, TNC content, and canopy gas exchange rates. Treatments were separated using the least significant difference (LSD) test at $P=0.05$.

\section{Results}

\subsection{Root thermotolerance}

Root biomass for both $A$. stolonifera and thermal $A$. scabra declined at the high soil temperature $\left(37^{\circ} \mathrm{C}\right)$, compared to the control at $20^{\circ} \mathrm{C}$ (Fig. 1). However, the reduction in root biomass was lower for thermal $A$. scabra (a $8 \%$ reduction) than for $A$. stolonifera (a $15 \%$ reduction). In general, thermal $A$. scabra plants had greater root biomass than $A$. stolonifera. Root cell membrane leakage, measured as amino acid leakage, of $A$. stolonifera increased significantly at $37^{\circ} \mathrm{C}$, as shown by the increased percent of amino acid leakage (Fig. 2). While increased membrane leakage also occurred in roots of thermal $A$. scabra at the high temperature, this change was not significantly different compared to that of the control plants at $20^{\circ} \mathrm{C}$. In addition, the maximum leakage for thermal $A$. scabra was $50 \%$, while the maximum leakage for $A$. stolonifera was $80 \%$ when both species were exposed to the high temperature (Fig. 2).

\subsection{Whole-plant carbon balance under prolonged high soil temperature}

Canopy net photosynthetic rate $(\mathrm{Pn})$ did not change with increasing soil temperature for thermal $A$. scabra, but decreased significantly for $A$. stolonifera at $37^{\circ} \mathrm{C}$ after 17 days of treatment (Fig. 3A). Canopy dark respiration rate was not affected by increasing temperature for thermal A. scabra, but increased significantly for $A$. stolonifera (Fig. 3B). The most profound differences between the two species in terms of changes in canopy photosynthetic and respiration rates with increasing soil temperature can be seen when 
total carbon consumption through respiration was subtracted from the total carbon fixation in photosynthesis (Fig. $3 \mathrm{C}$ ). At $20^{\circ} \mathrm{C}$, both species maintained a positive carbon gain; however, at $37^{\circ} \mathrm{C}$, there was a negative carbon budget for $A$. stolonifera, as opposed to a positive carbon gain for A. scabra (Fig. 3C).

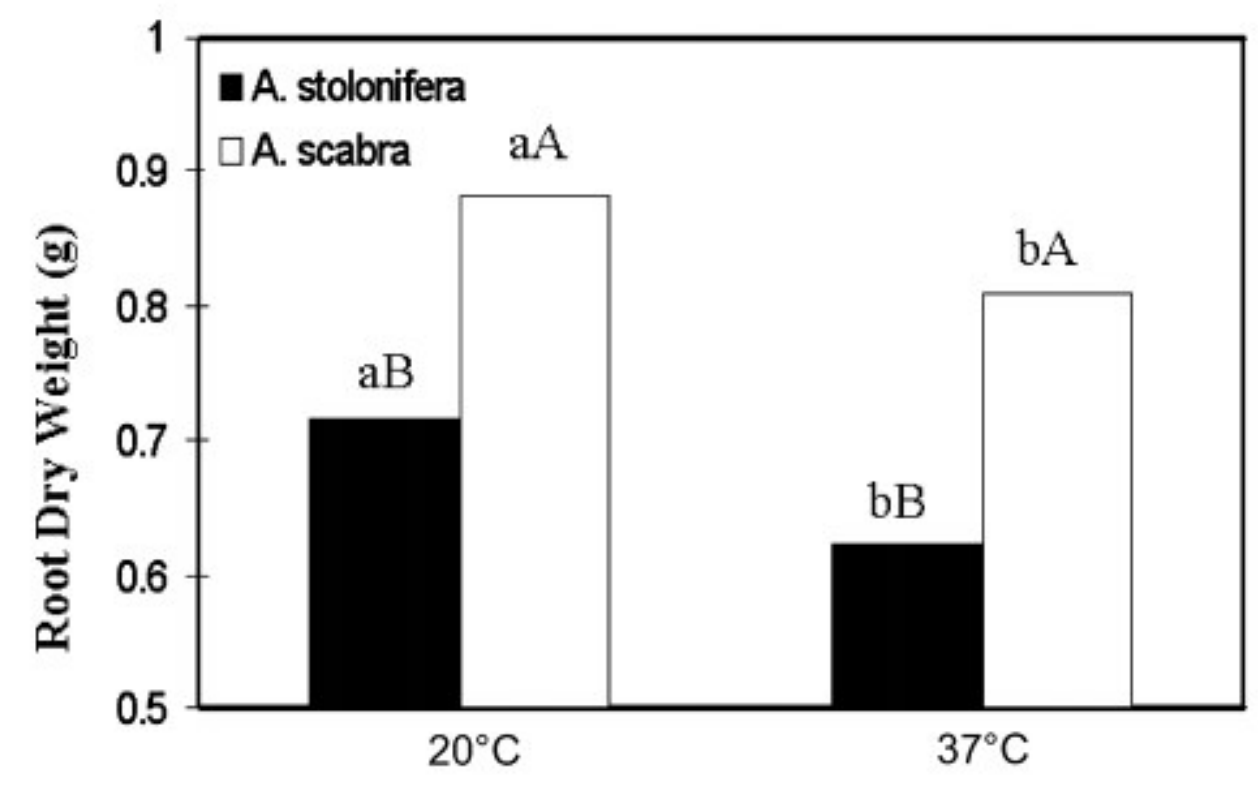

Temperature Treatment

Fig. 1. Root biomass for $A$. stolonifera and $A$. scabra in response to high soil temperature. Different lowercase letters indicate significant differences in root biomass between different temperature treatments $(P \leq 0.05)$ within a given species based on a LSD test. Different uppercase letters indicate differences between $A$. stolonifera and $A$. scabra at a given temperature treatment $(P \leq 0.05)$ based on a LSD test. 


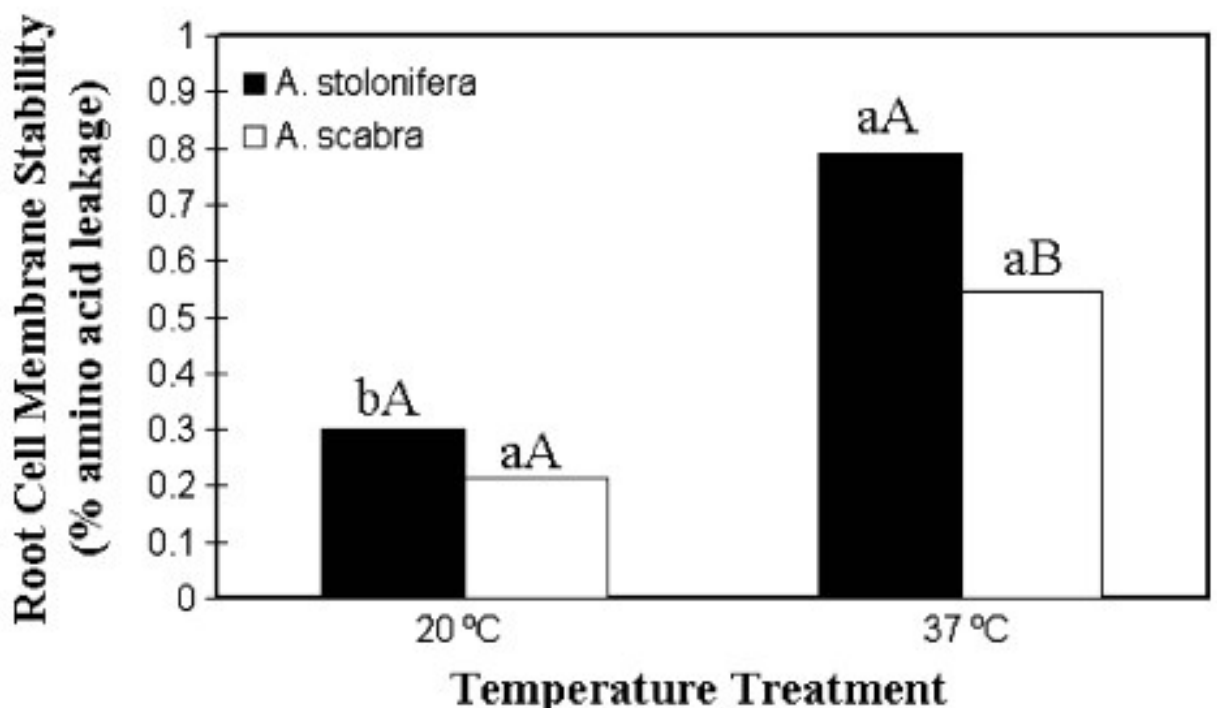

Fig. 2. Root cell membrane stability expressed as percent amino acid leakage for $A$. stolonifera and $A$. scabra in response to high soil temperature. Different lowercase letters indicate significant differences in cell membrane stability between temperature treatments $(P \leq 0.05)$ within a given species based on a LSD test. Different uppercase letters indicate differences between $A$. stolonifera and $A$. scabra at a given temperature treatment. 


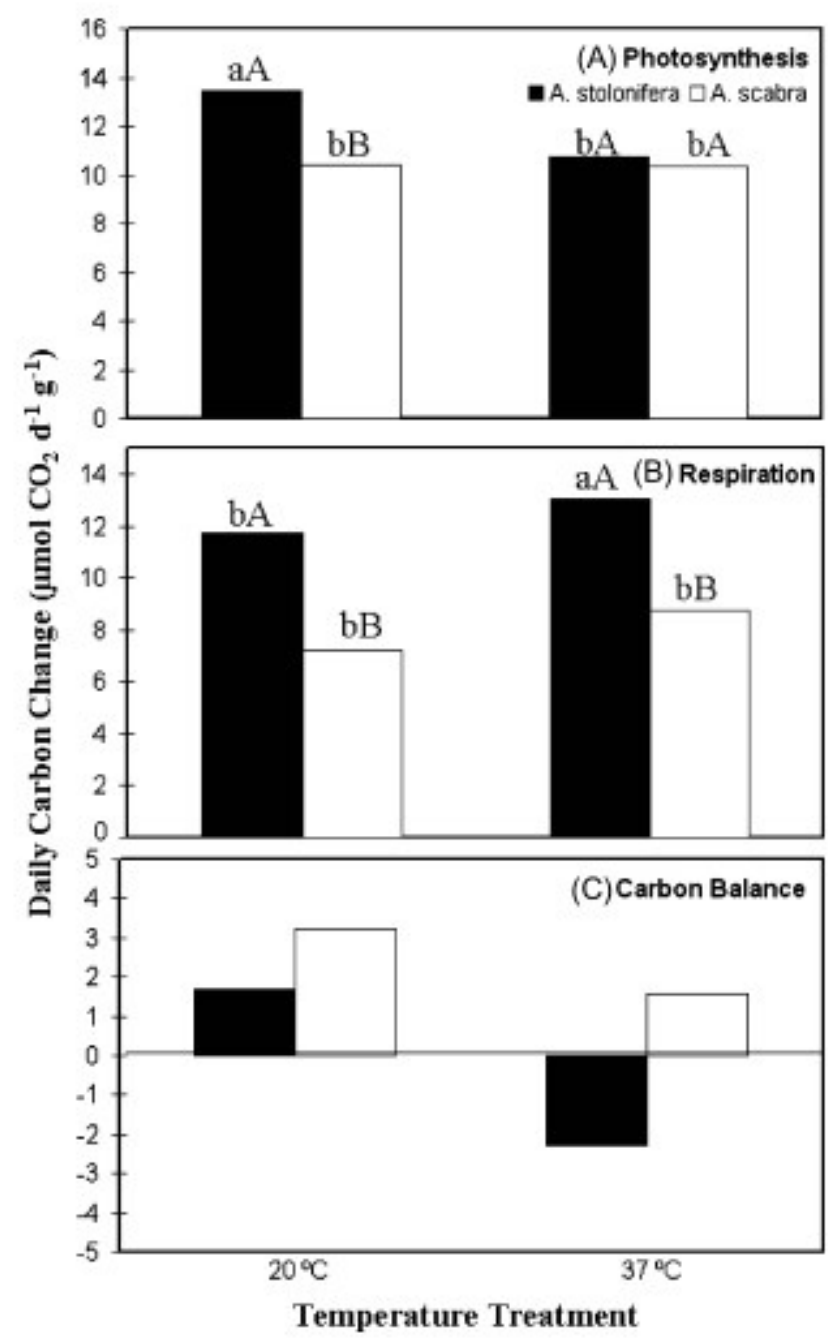

Fig. 3. Canopy photosynthetic rate $(A)$, respiration rate $(B)$, and carbon balance $(C)$ for $A$. stolonifera and $A$. scabra in response to high soil temperature. Different lowercase letters indicate differences in canopy photosynthetic rate, respiration rate, and carbon balance between temperature treatments $(P \leq 0.05)$ within a given species based on a LSD test. Different uppercase letters indicate differences between $A$. stolonifera and $A$. scabra at a given temperature treatment $(P \leq 0.05)$ based on a LSD test. 


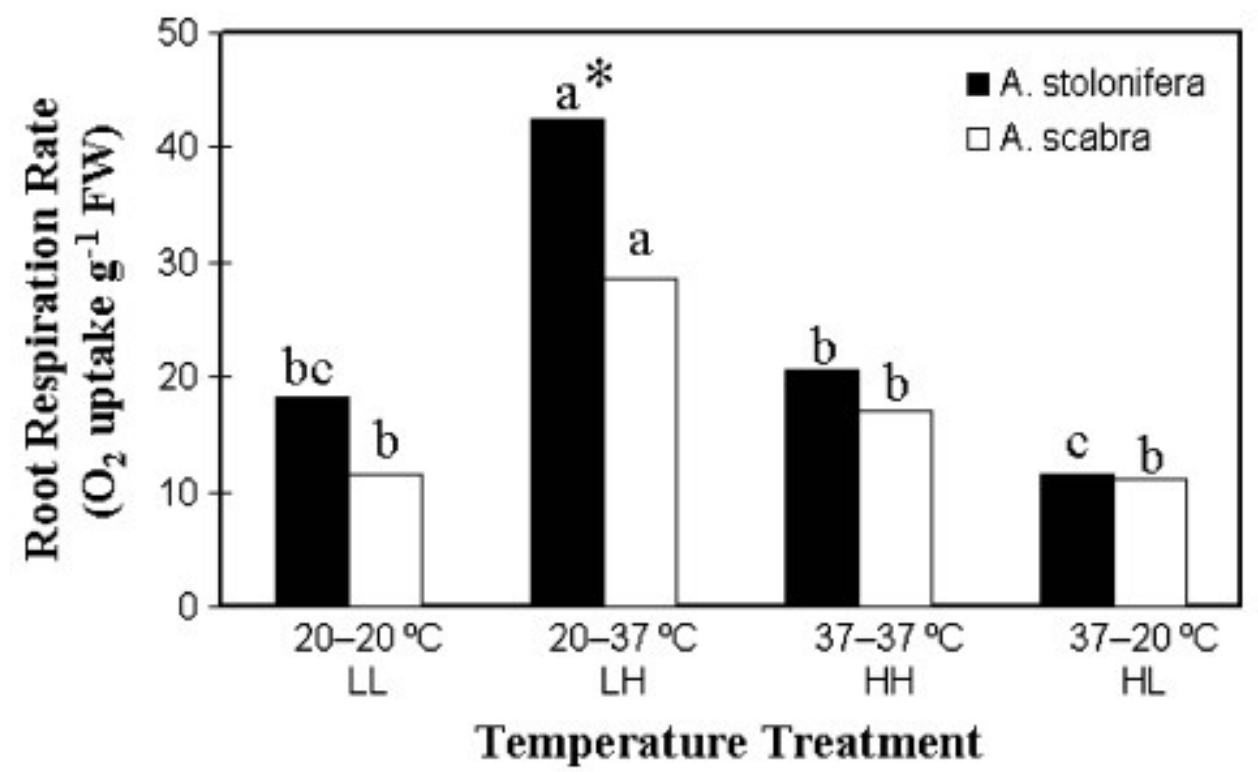

Fig. 4. Root respiration expressed as $\mathrm{O}_{2}$ consumption rate for $A$. stolonifera and $A$. scabra for plants grown at 20 or $37^{\circ} \mathrm{C}$ and measured at 20 or $37^{\circ} \mathrm{C}$. $\mathrm{HH}-$ grown and measured at $37^{\circ} \mathrm{C}, \mathrm{HL}-$ grown at $37^{\circ} \mathrm{C}$ and measured at $20^{\circ} \mathrm{C}$, $\mathrm{LH}-$ grown at $20^{\circ} \mathrm{C}$ and measured at $37^{\circ} \mathrm{C}, \mathrm{LL}-$ grown at $20^{\circ} \mathrm{C}$ and measured at $20^{\circ} \mathrm{C}$. Different lowercase letters indicate significant $(P \leq 0.05)$ difference between temperature treatments within a given species based on a LSD test. *Differences between $A$. stolonifera and $A$. scabra at a given temperature (LSD test, $\mathrm{P}<0.05)$.

\subsection{Root respiration rate in response to short-term temperature changes}

Short-term temperature responses of root respiration were evaluated by measuring oxygen consumption rate at 20 and $37^{\circ} \mathrm{C}$ after the plants grown at 20 or $37^{\circ} \mathrm{C}$ were transferred into nutrient solutions. Short-term temperature changes demonstrated the difference in the capacity of respiratory control between the two species (Fig. 4). Root respiration rates of $A$. scabra grown at $37^{\circ} \mathrm{C}$ did not change significantly when transferred to either $20(\mathrm{HL})$ or $37^{\circ} \mathrm{C}(\mathrm{HH})($ Fig. 4). Root respiration rate declined for $\mathrm{A}$. stolonifera when grown at $37^{\circ} \mathrm{C}$ and transferred to $20^{\circ} \mathrm{C}$. However, when plants previously grown at $20^{\circ} \mathrm{C}$ were transferred to high temperature $\left(37^{\circ} \mathrm{C}\right)(\mathrm{LH})$, root respiration rate increased dramatically for $A$. stolonifera. Root respiration rate for thermal $A$. scabra was less responsive to short-term temperature changes than that for A. stolonifera (Fig. 4). Thermal $A$. scabra maintained lower root respiration rates than $A$. 
stolonifera when previously grown at $20^{\circ} \mathrm{C}$ and transferred to $37^{\circ} \mathrm{C}(\mathrm{LH})$. Both $A$. stolonifera and thermal $A$. scabra exhibited lower respiration rates when previously grown and maintained at $37^{\circ} \mathrm{C}(\mathrm{HH})$ than when previously grown at $20^{\circ} \mathrm{C}$ and transferred to $37^{\circ} \mathrm{C}(\mathrm{LH})$.

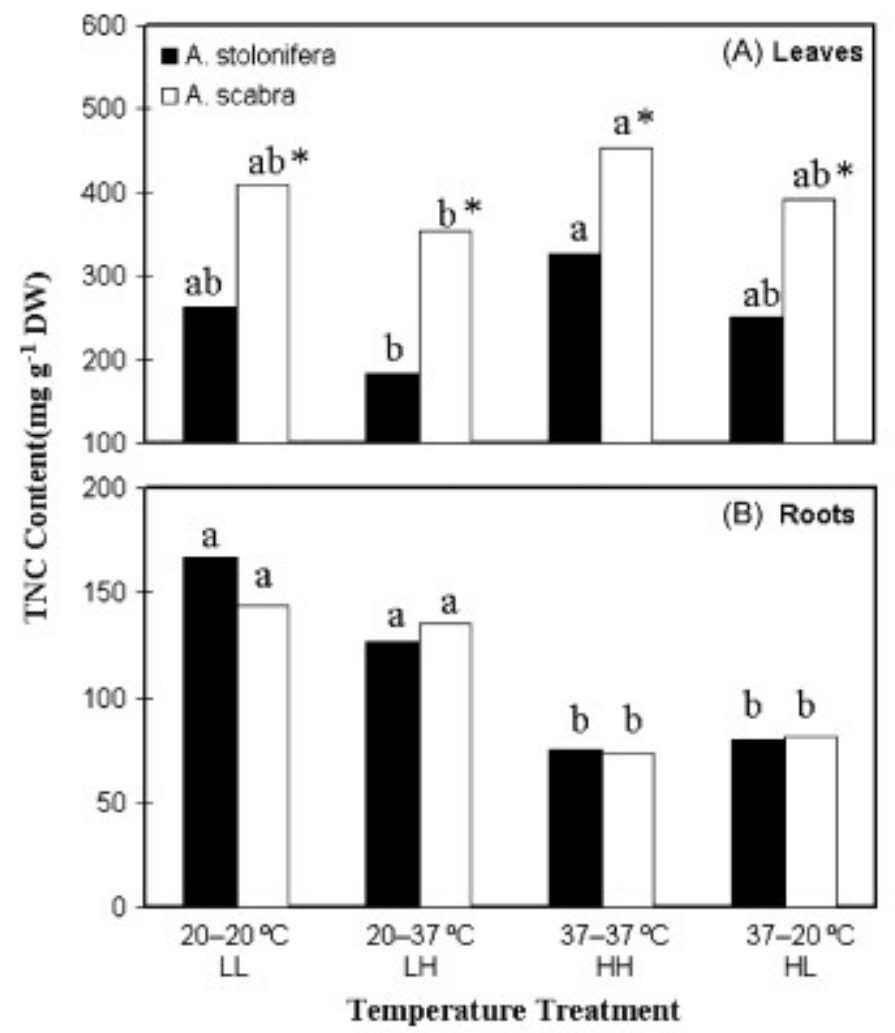

Fig. 5. Total non-structural carbohydrates in leaves $(A)$ and roots $(B)$ for $A$. stolonifera and $A$. scabra for plants grown at 20 or $37^{\circ} \mathrm{C}$ and measured at 20 or $37^{\circ} \mathrm{C}$. $\mathrm{HH}-$ grown and measured at $37^{\circ} \mathrm{C}, \mathrm{HL}$-grown at $37^{\circ} \mathrm{C}$ and measured at $20^{\circ} \mathrm{C}, \mathrm{LH}$-grown at $20^{\circ} \mathrm{C}$ and measured at $37^{\circ} \mathrm{C}, \mathrm{LL}-$ grown at $20^{\circ} \mathrm{C}$ and measured at $20^{\circ} \mathrm{C}$. Different lowercase letters indicate significant difference $(P \leq 0.05)$ between temperature treatments within a given species based on a LSD test. *Differences between $A$. stolonifera and $A$. scabra at a given temperature treatment (LSD test, $P \leq 0.05$ ).

\subsection{Carbohydrate content in response to short-term temperature changes}

Compared with A. stolonifera, $A$. scabra had higher TNC content in leaves under all temperature regimes (Fig. 5A). In addition, $A$. stolonifera showed a significant decrease in leaf TNC content after the short-term shift from 20 to $37^{\circ} \mathrm{C}(\mathrm{LH})$, whereas leaf TNC 
did not change in thermal $A$. scabra with the temperature increase (LH), compared to plants previously grown and maintained at $20^{\circ} \mathrm{C}(\mathrm{LL})$. TNC content of roots did not vary between the two species at $20(\mathrm{LL})$ or $37^{\circ} \mathrm{C}(\mathrm{HH})$, and both species grown for 17 days at $37^{\circ} \mathrm{C}(\mathrm{HH})$ had significantly less TNC in roots than those at $20^{\circ} \mathrm{C}(\mathrm{LL})$ (Fig. 5B). The shortterm change in temperature had no effect on TNC reserves in roots for both species.

\section{Discussion}

Cell membrane stability is positively related to the ability of cells to tolerate environmental stresses, including heat stress, and is widely used as a stress indicator (Rachmilevitch et al., 2006). The integrity of membranes is essential for many biochemical reactions, including respiration and carbon metabolism. Our data demonstrated that thermal $A$. scabra maintained higher root mass and membrane stability than $A$. stolonifera under high soil temperature, confirming that roots of thermal A. scabra were more thermotolerant.

Root thermotolerance of thermal Agrostis species could be related to efficient utilization and production of carbon. The importance of adequate carbon for growth and maintenance of roots has been well documented in many plant species, and shortage of assimilates due to high respiratory losses has long been proposed to be a primary factor responsible for root growth inhibition and dysfunction (Youngner and Nudge, 1968). Previous studies have suggested that root death of cool-season grass species at high temperature could be attributed to a net loss of carbon from the plant primarily resulting from excessive consumption of carbon through increased respiration and a reduction in carbon assimilation in photosynthesis (Carrow, 1996; Huang and Gao, 2000; Xu and Huang, 2000b; Liu and Huang, 2001). In a study with three bluegrass species (Poa pratensis L., Poa trivialis L., Poa compressa L.), photosynthetic rate was reduced by $47 \%$ and dark respiration was increased by $42 \%$ by increasing temperature from $23 / 15 \circ \mathrm{C}$ (day/night) to $35 / 25 \circ \mathrm{C}$ (Watschke et al., 1972). Increases in dark respiration rates have also been associated with lower biomass production in tall fescue (Festuca arundinacea L.), suggesting that excessive dark respiration may adversely affect growth rates (Volenec, 1984). In the present study, it is interesting to find that 
thermal $A$. scabra exposed to $37^{\circ} \mathrm{C}$ for 17 days maintained canopy net photosynthetic rate $(\mathrm{Pn})$ and respiration rate at the same levels as those plants exposed to $20^{\circ} \mathrm{C}$. In contrast, $\mathrm{Pn}$ decreased and respiration rate increased with increasing soil temperature from 20 to $37^{\circ} \mathrm{C}$ for $A$. stolonifera. In addition, under high soil temperature conditions, thermal $A$. scabra had a positive carbon gain, whereas $A$. stolonifera had a net loss of carbon, which may have resulted in carbon starvation and death of roots. Our results suggest that the maintenance of high carbon fixation, low carbon consumption rate, and a positive carbon balance could be a critical factor controlling root survival of thermal grass species when exposed to prolonged periods of high soil temperature. However, the underlying factors for high thermal stability of photosynthesis and respiration processes in thermal $A$. scabra are unknown, which deserves further investigation. Heat tolerant roots may be able to control respiration rate or use efficient respiratory pathways. Increasing temperature from 16 to $20^{\circ} \mathrm{C}$ caused a $30 \%$ increase in root respiration rates in three perennial grasses, Bellis perennis, Dactylis glomerata, and Poa annua, but $B$. perennisthat was acclimated to higher temperature maintained a lower respiration rate than the other species under high temperature conditions (Gunn and Farrar, 1999). In this study, short-term temperature responses of root respiration demonstrated that thermal $A$. scabra was able to down-regulate or control respiration rates at a lower level, which exhibited the same rate of respiration in roots grown and maintained at $37^{\circ} \mathrm{C}$ as those plants grown at $20^{\circ} \mathrm{C}$ but transferred to $37^{\circ} \mathrm{C}$ for $24 \mathrm{~h}$. Furthermore, thermal $A$. scabra grown at $20^{\circ} \mathrm{C}$ maintained a relatively low respiration rate when transferred to $37^{\circ} \mathrm{C}$, compared to $A$. stolonifera that exhibited a more dramatic increase in root respiration rate in response to the short-term temperature elevation. In general, root respiration rate for thermal $A$. scabra was less responsive to short-term temperature changes than that for $A$. stolonifera. Down-regulation of root respiration may contribute to the thermal grass adaptation to elevated temperature.

The ability of a plant to maintain root viability is regulated by both the total amount of carbon assimilated by foliages during photosynthesis and by the amount of carbon allocated to the belowground system (Bloomfield et al., 1996). A reduction in carbohydrate reserves in roots has been correlated with decreased root growth in 
several plant species (Aldous and Kaufmann, 1979; Sweeney et al., 2001; Xu and Huang, 2003). In this study, root TNC content was significantly lower in plants grown at $37^{\circ} \mathrm{C}$ compared to those at $20^{\circ} \mathrm{C}$ for both species. The reduction in root TNC content corresponded with decreased root biomass at the high soil temperature in both Agrostis species. However, root TNC content was not different between the two species at low or high temperature and did not change with the short-term (24 h) temperature change. This suggested that while root TNC levels could be important for root survival of longterm high soil temperature, short-term responses of TNC to changes in temperature could not explain the differences in root thermotolerance between the two species. However, thermal $A$. scabra exhibited significantly greater amount of TNC in leaf tissues than $A$. stolonifera, particularly when grown at low temperature and transferred to high temperature. It should be noted that only roots were exposed to high soil temperature while shoots were exposed to its optimum growth temperature $\left(20^{\circ} \mathrm{C}\right)$ in our study. Therefore, more TNC accumulation in leaves that were exposed to the optimal temperature may aid in the whole-plant survival under high soil temperature conditions.

In summary, the ability of thermal $A$. scabra to down-regulate or control root respiration at a relatively lower level under long-term or short-term heat stress, compared to heatsensitive $A$. stolonifera, may be evidence of an acclimation mechanism allowing it to conserve carbon in response to increasing temperature. This mechanism, coupled with the ability to maintain high canopy photosynthesis and low whole-plant respiration rates, may be essential in the adaptation of cool-season, perennial grasses to prolonged periods of high soil temperature. Such mechanisms could be utilized for selection of improved heat tolerance in heat-sensitive cool-season grass species, such as $A$. stolonifera.

\section{Acknowledgements}

The study was funded by USDA-NRI (\#2003-00759) and United States Golf Association. The authors express thanks to Shimon Rachmilevitch, Steve McCann, and Yan Xu for critical review of the manuscript. 


\section{References}

Aldous, D.E., Kaufmann, J.E., 1979. Role of root temperature on shoot growth of two Kentucky bluegrass cultivars. Agron. J. 71, 545-547.

Bloomfield, J., Vogt, K., Wargo, P., 1996. Tree root turnover and senescence. In: Waisel, Y., Eshel, A., Kafkafi, U. (Eds.), Plant Roots: The Hidden Half. Marcel Dekker, New York.

Carrow, R.N., 1996. Drought resistance aspects of turfgrasses in the southeast: rootshoot responses. Crop Sci. 36, 687-694.

Du, C.D., Tachibana, S., 1994. Effect of supraoptimal root temperature on the growth, root respiration, and sugar content of cucumber plants. Sci. Hortic. 58, 289-301.

Fry, J., Huang, B., 2004. Applied Turfgrass Physiology. John Wiley \& Sons Inc., Hoboken, NJ.

Gunn, S., Farrar, J.F., 1999. Effects of a 4 C increase in temperature on partitioning of leaf area and dry mass, root respiration and carbohydrates. Funct. Ecol. 13, 1220.

Hoagland, D.R., Arnon, D.I., 1950. The water-culture method for growing plants without soil. Calif. Agric. Exp. Sta. Circ., 347.

Huang, B., Gao, H., 2000. Growth and carbohydrate metabolism of creeping bentgrass in response to increasing temperature. Crop Sci. 40, 1115-1120.

Klock, K.A., Taber, H.G., Graves, W.R., 1997. Root respiration and phosphorus nutrition of tomato plants grown at a 36 degrees $\mathrm{C}$ root-zone temperature. J. Am. Soc. Hortic. Sci. 122, 175-178.

Kuroyanagi, T., Paulsen, G.M., 1988. Mediation of high-temperature injury by roots and shoots during reproductive growth of wheat. Plant Cell Environ. 11, 517-523.

Lambers, H., Atkin, O.K., Millenaar, F.F., 1999. Respiratory patterns in roots in relation to their functioning. In: Waisel, Y., Eshel, A., Kafkafi, U. (Eds.), Plant Roots: The Hidden Half. Marcel Dekker, New York.

Larkindale, J., Huang, B., 2004. Changes of lipid composition and saturation level in leaves and roots for heat-stressed and heat-acclimated creeping bentgrass (Agrostis stolonifera). Environ. Exp. Bot. 51, 57-67.

Liu, X., Huang, B., 2001. Seasonal changes and cultivar differences in turf quality, photosynthesis, and respiration of creeping bentgrass. HortScience 36, 11311135.

Liu, X., Huang, B., 2002. Mowing effects on root production, turnover, and mortality in three creeping bentgrass cultivars. Crop Sci. 42, 1241-1250.

McMichael, B.L., Taylor, H.M., 1987. Applications and limitations of rhizotrons and minirhizotrons. In: Taylor, H.M. (Ed.), Minirhizotron Observation Tubes: Methods 
and Applications for Measuring Rhizosphere Dynamics. American Society of Agronomy Inc., Madison, WI, pp. 1-14.

McMichael, B.L., Burke, J., 1999. Temperature effects on root growth. In: Waisel, Y., Eshel, A., Kafkafi, U. (Eds.), Plant Roots: The Hidden Half. Marcel Dekker, New York. Nielsen, K.F., 1974. Roots and root temperature. In: Carson, E.W. (Ed.), The Plant Root and its Environment. University Press Virginia, Charlottesville, VA, pp. 293-333.

Pote, J., Wang, Z., Huang, B., in press. Timing and temperature of physiological decline in creeping bentgrass. J. Am. Soc. Hortic. Sci.

Rachmilevitch, S., DaCosta, M., Huang, B., 2006. Physiological and biochemical indicators for stress tolerance. In: Huang, B. (Ed.), Plant-Environment Interactions, 3rd ed. CRC Press, Boca Raton, FL. Rosen, H., 1957. A modified ninhydrin colorimetric analysis for amino acids. Arch. Biochem. Biophys. 67, 1015.

Ruter, J.M., Ingram, D.L., 1990. 14Carbon-labeled photosynthate partitioning in Ilex crenata at supraoptimal root-zone temperature. J. Am. Soc. Hortic. Sci. 115, 1008-1013.

Ruter, J.M., Ingram, D.L., 1992. High root-zone temperature influence RuBisCO activity and pigment accumulation in leaves of 'Rotundifolia' holly. J. Am. Soc. Hortic. Sci. 117, 154-157.

Stout, R.G., Al-Niemi, T., 2002. Heat-tolerant flowering plants of active geothermal areas in Yellowstone National Park. Ann. Bot. 90, 259- 267.

Sweeney, P., Danneberger, K., Wang, D.J., McBride, M., 2001. Root weight, nonstructural carbohydrate content, and shoot density of high-density creeping bentgrass cultivars. HortScience 36, 368-370.

Tercek, M.T., Hauber, D.P., Darwin, S.P., 2003. Genetic and historical relationships among geothermally adapted Agrostis (bentgrass) of North America and Kamchatka: evidence for a previously unrecognized, thermally adapted taxon. Am. J. Bot. 90, 1306-1312.

Ting, S.V., 1959. Rapid colorimetric methods for simultaneous determination of total reducing sugars and fructose in citrus juices. Fruit Juice Assoc. 4, 263-266.

Udomprasert, N., Li, P.H., Davis, W., Markhart, A.H., 1995. Root cytokinin level in relation to heat tolerance of Phaseolus acutifolius and Phaseolus vulgaris. Crop Sci. 35, 486-490.

Volenec, J.J., 1984. Dark respiration, non-structural carbohydrates, and elongation of tall fescue leaves. Dissertation Abstracts International, B 44, p. 2960.

Watschke, T.L., Schmidt, R.L., Carson, E.W., and Blaser, R.E., 1972. Some metabolic phenomena of Kentucky bluegrass under high temperature. Crop Sci. 12, 87-90. 
Xu, Q., Huang, B., 2000a. Growth and physiological responses of creeping bentgrass to differential shoot and root temperature. Crop Sci. 40, 1363-1368.

Xu, Q., Huang, B., 2000b. Effects of air and soil temperature on carbohydrate metabolism in creeping bentgrass. Crop Sci. 40, 1368-1374.

Xu, Q., Huang, B., 2001. Lowering soil temperature improves creeping bentgrass growth under heat stress. Crop Sci. 41, 1878-1883.

Xu, Q., Huang, B., 2003. Seasonal changes in carbohydrate accumulation for two creeping bentgrass cultivars. Crop Sci. 43, 266-271.

Youngner, V.B., Nudge, F.G., 1968. Growth and carbohydrate storage of three Poa pratensis L. strains as influenced by temperature. Crop Sci. 8, 455-456. 